\title{
INFLUENCE OF LINEAR PROFILE MODIFICATIONS ON THE DYNAMIC LOADING OF A SPUR GEAR
}

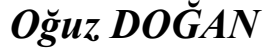 \\ Onur Can KALAY \\ Fatih KARPAT
}

Received: 23.11.2020; revised: 20.05.2021; accepted: 21.05.2021

\begin{abstract}
Gear dynamics is one of the most critical subjects in gear design because of its remarkable effect on vibration levels, load-carrying capacity, and noise. The tip relief modification is known as a simple method to decrease dynamic loads in the industry. The primary goal of this study is to understand the influence of tip relief modification on the dynamic performance of the spurs gears. In this paper, the meshing process and gear mesh stiffness calculation method are defined. A dynamic model with twodegree-of-freedom is created to find the dynamic response of the spur gear pair. The simulations are carried out with standard and different tip modified spur gear pairs. It is observed that the tip relief modification has an excellent effect on the gear dynamic response. However, this effect is restricted until a certain amount of tip relief modification. After the optimum amount of tip relief modification, the dynamic loads are increased considerably. Thus, a computer program is developed to find the optimum amount of tip relief modification in MATLAB ${ }^{\circledR}$ for the gear designers. The program outputs are given for two different case studies. As a result of the study, the dynamic factor behaves like a "V form" according to the tip relief modification, and the dynamic force decreased approximately $25 \%$ for optimum profile modification.
\end{abstract}

Keywords: Gear Dynamics, Tip Relief, Spur Gear, Mesh Stiffness

\section{Doğrusal Profil Modifikasyonlarının Bir Düz Dişli Çarkın Dinamik Yüklenmesi Üzerine Etkisi}

Öz: Dişli dinamiği; titreşim seviyeleri, yük taşıma kapasitesi ve gürültü üzerindeki dikkat çekici etkileri sebebi ile dişli çark tasarımındaki en kritik unsurlardan bir tanesidir. Dişli çark uç modifikasyonu endüstride dişli çarklar üzerindeki dinamik kuvvetleri azaltmak için kullanılan bir yöntem olarak bilinmektedir. Bu çalışmanın amacı; dişli uç modifikasyonunun düz dişli çarkların dinamik performansı üzerindeki etkilerinin anlaşılmasıdır. Bu kapsamda, düz dişli çarkların kavrama sürecine ve kavrama rijitliğinin hesaplamasına yönelik bir yöntem tanımlanmıştır. Dişli çark çiftinin dinamik cevabının bulunması için iki serbestlik dereceli bir dinamik model geliştirilmiştir. Dişli uç modifikasyonun dişli çarkların dinamik performansı üzerindeki etkilerinin incelenmesi için nümerik simülasyonlar hem standart hem de uç modifikasyonu uygulanmış dişli çark çiftleri için gerçekleştirilmiştir. Uç modifikasyonu uygulamasının dişli çarkların dinamik cevabı üzerinde mükemmel bir etkisi olduğu tespit edilmiştir. Ancak, belirtilen bu pozitif etkinin de belirli bir optimum değer ile sınırlı olduğu görülmüştür. Optimum dişli uç modifikasyonu miktarı aşıldıktan sonra dişli çark üzerindeki dinamik yükler ciddi bir şekilde artmaktadır. Bu çalışmada, MATLAB $^{\circledR}$ ortamında dişli çark tasarımcılarının optimum uç modifikasyonu miktarını hesaplamasına olanak sağlayacak bir bilgisayar programı geliştirilmiştir. Program çıktıları iki farklı vaka çalışması için değerlendirilerek sunulmuştur. Sonuç olarak, dinamik faktörün profil modifikasyonu ile birlikte $\mathrm{V}$ formda değiştiği ve optimum modifikasyon değerinde yaklaşık olarak \%25 azaldığ 1 tespit edilmiştir.

\footnotetext{
* Kahramanmaras Sutcu Imam University, Department of Mechanical Engineering, 46050, Kahramanmaras, Turkey

** Bursa Uludag University, Department of Mechanical Engineering, 16059, Bursa, Turkey

Correspondence Author: Oğuz Doğan (oguzdogan@ksu.edu.tr)
} 
Anahtar Kelimeler: Dişli Dinamiği, Uç Modifikasyonu, Düz Dişli, Kavrama Rijitliği

\section{INTRODUCTION}

Gears are one of the most critical transmission elements in machinery systems. Due to the high load capacity, durability, constant reduction ratio, etc., they are used in many industries, such as automotive, energy, and aerospace industries. With the increasing demand for alternative energy sources such as wind energy, especially wind turbines, the gears become more critical with their load-carrying capacity and vibration levels. Thus, gear design has become an essential issue for designers. Moreover, the demanding performance from gearboxes is increasing day by day because demanding power and speed values are increased too. Therefore, wind turbine gearboxes need to satisfy these conditions for being appropriate to today's requirements by meeting features such as dynamic loads, vibration, and noise problems.

During the design process of the gearboxes, the resonance frequencies should also be known, and the vibration levels and dynamics forces should be detected for the most suitable design. Furthermore, the dynamic loads, vibrations levels, and noise should be minimized. For these aims, many researchers studied on dynamic analysis of gear systems in the literature. Karpat et al. (2008) developed a dynamic model for asymmetric gears. The effects of drive side pressure angle on the dynamic response of the spur gears were investigated numerically. As a result of the study, it is observed that when the pressure angle increases, the dynamic teeth loads are increasing too. Lin et al. (1990a, 1990b) studied gear dynamics with a 4-DOF gear dynamic model. The effects of rotating speed, applied load, damping factor, and gear inertia on gear dynamic response are investigated, and the results are compared with AGMA empirical formula and previous studies. Marques et al. (2016) also developed a 4-DOF dynamic model to understand the effect of gear dynamics and gear geometry on power loss. Ozguven (1991) developed a 6-DOF nonlinear semidefinite gear dynamic model to understand the effect of the shaft and bearing dynamics on the whole gearbox dynamics.

A wind turbine is a complex system in which design is a matter of constant tradeoff between the competing demands of lower cost, better energy production, increased lifetime, reliability and durability, and maintenance cost. The gearbox is a crucial and expensive wind turbine component and has experienced higher than expected failure rates caused by the dynamic loads. Thus, the importance of the dynamic behavior of the wind turbine gearboxes investigated in the literature (Alemayehu and Ekwaro-Osire, 2014; Wei et al., 2015; Ding et al., 2018; Guerine et al., 2017).

The primary goal for the designers is to decrease dynamic tooth loads. In the literature, different ways are used to decrease dynamic loads. The contact ratio has a significant effect on dynamic loads. Liou et al. (1996) developed 4-DOF dynamic model and investigated the effect of contact ratio on gear dynamic response with no modification. It is obtained that when the contact ratio increase, the dynamic loads also decrease considerably. Karpat et al. (2008) investigated the dynamic performances of the high contact ratio spur gears with asymmetric teeth. A mathematical model and a computer program were created for the calculation of dynamic contact loads. As a result of the study, it is observed that the dynamic performance of the asymmetric HCR spur gears is better than the symmetric spur gears. Tooth stiffness, which constantly varies during the meshing process, is one of the most influential factors affecting gear dynamic behavior. Karpat et al. (2020) developed an experimental methodology to measure the single tooth stiffness of both symmetric and asymmetric spur gears. Moreover, the results obtained are verified with the finite element method. It is observed that the asymmetric spur gears performed better than symmetric spur gears in terms of single tooth stiffness.

Tip relief modification is also a powerful method to minimize the dynamic loads in gearboxes. The tip relief modification is defined as; extracting material from the tip region. The tip relief modification is preferred in the literature for different purposes. Marković et al. (2011) investigated the effect of tip relief profile modification on spur gear contact stress. As a result, Hertzian contact stress suddenly changes when the single tooth contact starts in the unmodified 
gear pair. However, with tip relief modification, the stress changes more slightly. The researchers also studied the influence of tip relief modification on tooth root and flank stresses (Marković and Vrcan, 2016). Palmer et al. (2012) investigated the effects of tip relief on transmission error, stress, and gear noise by using numerical methods for both low contact ratio and high contact ratio spur gears. Shanmugasundaram et al. (2014) studied the effect of tip relief modification and pressure angle on the life of gear systems. Karpat et al. (2008) investigated the effects of tip relief modification on symmetric and asymmetric spur gears wear. A 2-DOF dynamic model was created, and the tooth wear analysis was done. When the amount of tip relief modification increases, the wear depths decrease. However, if the amount of modification increases too much, wear is also increased.

The amount of tip relief modification is also a critical issue for designers. After a certain amount of tip relief modification, the advantages of tip relief modification turn into disadvantages, and dynamic loads increase. Therefore, an optimization study is needed to define the optimum amount of tip relief modification.

Hu et al. (2016) investigated the effect of different tooth profile modifications on the dynamic response of the high-speed gear systems. A mathematical dynamic model was created for the definition of dynamic response. Short and long profile modifications were applied to the gear system. It is obtained that the dynamic response of the gears with the short profile modification is better than the gears with the long profile modification. However, after a certain amount of short profile modification, the dynamic performance of the gear system gets worse. Liu et al. (2016) developed a 10-DOF dynamic model, including different modification lengths and types; with the increase of modification amount, the dynamic factor follows the "V" type pattern. The optimum modification amount was defined with the optimization process. Yoon et al. (1996) used a new cubic spline profile to minimize static transmission error. The authors develop a 4-DOF dynamic model and analyzed standard and modified spur gear dynamic performances. As a result of the study, it can be said that the cubic spine gear tooth profile is very suitable for the dynamic response of the gear systems. Moreover, there are many studies in the literature about the optimization process of the tip relief modification; different optimization methods are discussed in the following studies (Tharmakulasingam et al., 2008; Tharmakulasingam, 2009; Lin et al., 1994).

Although there are many analytical and numerical studies in the literature, there are few experimental studies. Thus experimental studies need comprehensive and complicated setups like back to back. Kahraman et al. (1999) investigated the effects of tip relief on the dynamic behavior of spur gear pairs by using experimental tests. Linear involute tip relief modification is conducted for the test gears. The amount of dynamic transmission error was measured from the experimental test setup, and frequency response curves were given for each system. Baud et al. (2002) validated their numerical finite element code with experimental test data for the one-stage spur and helical gear systems. Besides, the influence of tip relief was investigated with both methods. Yildirim et al. (1999) were developed as an approach for relief design for LCR and HCR spur gears. The effect of tip relief modification was investigated experimentally. The advantages of HCR gear concerning transmission error are discussed.

In this paper, the effects of short linear tip relief on dynamic tooth loads and frequency response regarding two different cases are investigated. The gear mesh stiffness is calculated by using the finite element method. Besides, the dynamic tooth loads are calculated with a dynamic model in MATLAB ${ }^{\circledR}$ (MathWorks Inc., MA, USA) for both cases. A computer program is created to find minimum dynamic forces and the optimum amount of tip relief.

\section{MATERIALS AND METHODS}

\subsection{Mesh Analysis of Low Contact Ratio Spur Gears and Mesh Stiffness}

Gear mesh stiffness is one of the most crucial parameters for the dynamic analysis of spur gear systems. In the literature, there are different ways presented for the calculation of gear mesh 
stiffness. The single tooth stiffness values for each point are calculated according to Karpat et al. (2017) by Eq. (1-4).

$$
\begin{aligned}
& k_{1,1}=\frac{P}{x_{1,1}} \\
& k_{2,1}=\frac{P}{x_{2,1}} \\
& k_{1,2}=\frac{P}{x_{2,2}} \\
& k_{2,2}=\frac{P}{x_{2,2}}
\end{aligned}
$$

where,

$P=$ applied load on the tooth profile, $(\mathrm{N})$

$x=$ total deformation on the tooth geometry, $(\mathrm{mm})$

$k_{1}, k_{2}=$ single tooth stiffness of the pinion and gear, $(\mathrm{N} / \mathrm{mm})$

The meshing process of the spur gears starts at the point of "A" in Figure 1. Also, a second gear pair is in contact at the point of "D." The region is named the double tooth pair contact region. When the first gear pair reached point "B," the second gear pair contact ends. Thus, this point is specifically named the Lowest Point of Single Tooth Contact (LPSTC). The radii of LPSTC can be calculated with Eq. (5). After point "B," one tooth pair continues to contact until point "D." The region between $\mathrm{B}-\mathrm{D}$ is defined as the single tooth contact region. Also, the point " $D$ " is named as the Highest Point of Single Tooth Contact (HPSTC). The radii of HPSTC can be calculated with Eq. (6). After the HPSTC, the meshing process continues with two gear pairs until the end of the contact point "E."

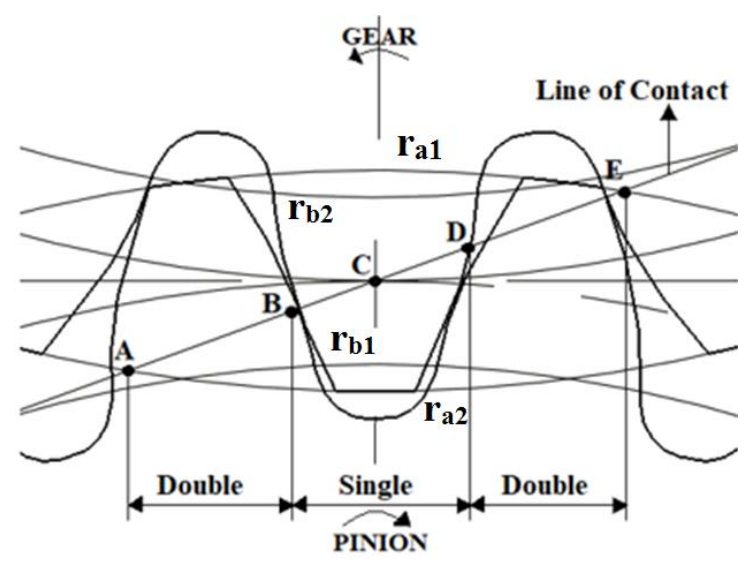

Figure 1:

Meshing process of the low contact ratio spur gears

$$
r_{L P S T C}=\left[r_{b 1}^{2}+\left(\left(r_{a 1}^{2}-r_{b 1}^{2}\right)^{0.5}-\pi m_{n} \cos \alpha_{0}\right)^{2}\right]^{0.5}
$$




$$
r_{H P S T C}=\left[r_{b 1}^{2}+\left(\left(r_{b 1}+r_{b 2}\right) \tan -\left(r_{a 2}^{2}-r_{b 2}^{2}\right)^{0.5}+\pi m_{n} \cos \alpha_{0}\right)^{2}\right]^{0.5}
$$

where,

$m_{n}=$ normal module of the gears, $(\mathrm{mm})$

$r_{a 1}, r_{a 2}=$ addendum circles of pinion and gear, $(\mathrm{mm})$

$r_{b 1}, r_{b 2}=$ base circles of the pinion and gear, $(\mathrm{mm})$

$\alpha_{0}=$ pressure angle, $(\mathrm{deg})$

Equivalent stiffness between the first pair of teeth:

$$
K_{1}=\frac{k_{2,1} k_{1,1}}{k_{2,1}+k_{1,1}}
$$

Equivalent stiffness between the second pair of teeth:

$$
K_{2}=\frac{k_{2,2} k_{1,2}}{k_{2,2}+k_{1,2}}
$$

If the contact between $\mathrm{B}-\mathrm{D}$ in the single tooth region:

$K_{l} \neq 0$ and $K_{2}=0$

If the contact between $\mathrm{A}-\mathrm{B}$ or $\mathrm{D}-\mathrm{E}$, in the double tooth contact region:

$K_{1} \neq 0$ and $K_{2} \neq 0$

\subsection{Tip Relief Modification}

Tip relief modification is commonly referred to as decrease dynamic loads, noise, and vibration. The tip relief modification is done by removing material from the top of the gear tooth. Moreover, the tip relief modification can be achieved in various ways, such as linear, parabolic, short, or long. In this study, linear short tip relief modification is performed for the gear profiles. Figure 2 shows a modified and unmodified involute profile of spur gears for linear short tip relief. The tip relief modification has two design parameters. $\Delta l$ is defined as the amount of tip relief, and " $L$ " is defined as the length of the relief. The tip relief begins at the point "D," HPSTC, and ends at the point "E" on the addendum circle of the gear.

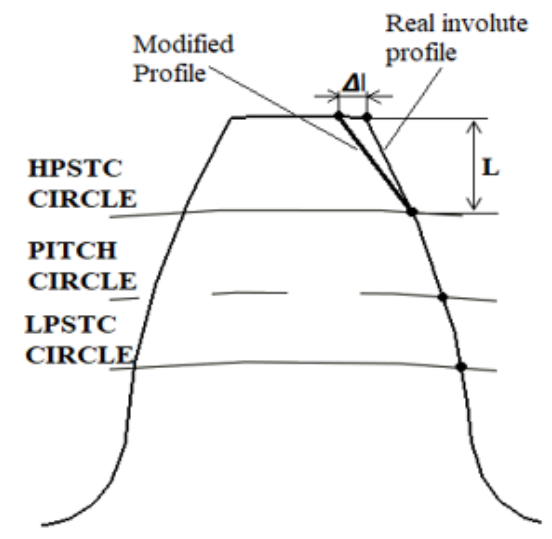

Figure 2:

Tip relief modification on a tooth 


\subsection{Dynamic Model of Spur Gear Pair}

Due to the vibration of the gears, the torque transmission is not stable, and the dynamic forces occur on the gear teeth. A parametric dynamic model is developed to calculate dynamic forces. In the literature, there is a various number of the dynamic model available. In this study, the twodegree-of-freedom dynamic model is proposed. The equations of motions are derived from using the free body diagram of spur gear teeth pair in Figure 3.
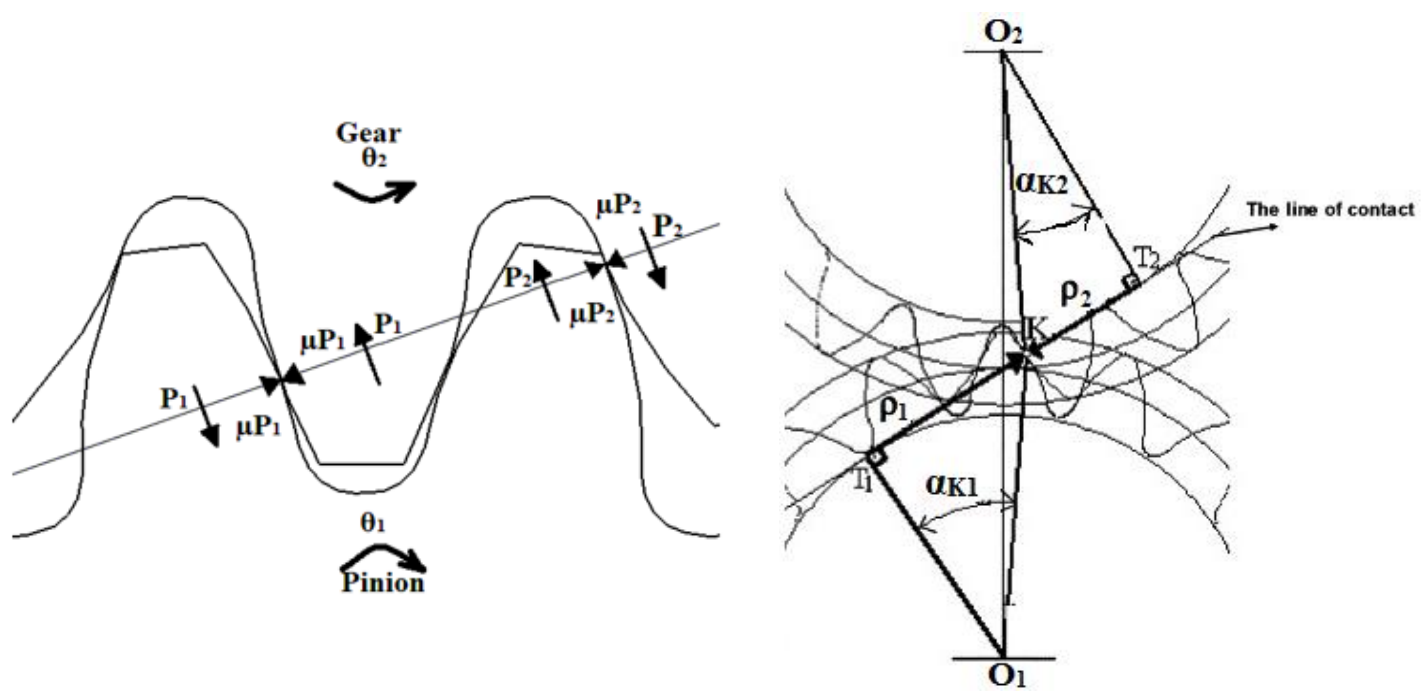

Figure 3:

Free body diagram of engaging spur gear teeth and radius of curvature at the contact point

$$
\begin{gathered}
J_{1} \ddot{\theta}_{1}=P_{1} r_{b 1}-r_{b 1}\left(P_{1}+P_{2}\right) \pm \rho_{1,1} \mu_{1} P_{1} \pm \rho_{1,2} \mu_{2} P_{2} \\
J_{2} \ddot{\theta}_{2}=r_{b 2}\left(P_{1}+P_{2}\right)-P_{2} r_{b 2} \pm \rho_{2,1} \mu_{1} P_{1} \pm \rho_{2,2} \mu_{2} P_{2}
\end{gathered}
$$

where,

$\theta_{1}, \theta_{2}=$ angular displacements, $(\mathrm{rad})$

$J_{1}, J_{2}=$ polar mass moment of inertias of pinion and gear, $\left(\mathrm{kgm}^{2}\right)$

$\mu_{1}, \mu_{2}=$ coefficient of friction, (-)

$\rho_{1}, \rho_{2}=$ radius of curvature pinion and gear, $(\mathrm{mm})$

In the equation of motion, $J_{1}$ and $J_{2}$ are the polar mass moment of inertia of pinion and gear. $P_{1}$ and $P_{2}$ are the dynamic forces between gear teeth. $\rho_{1}$ and $\rho_{2}$ are the radii of curvature, $\mu_{1}$ and $\mu_{2}$ are the coefficients of friction which varies according to the contact point. $r_{b 1}$ and $r_{b 2}$ are the base circles of the pinion and gear; thus, the $P_{1} r_{b 1}$ and $P_{2} r_{b 2}$ are defined as the transmitted torque.

The equations of motions are derived according to the angular positions of the gear. The linear positions of the gears are preferred to make solutions easy.

$$
\begin{aligned}
& x_{1}=r_{b 1} \theta_{1} \\
& x_{2}=r_{b 2} \theta_{2}
\end{aligned}
$$


The relative expressions of the displacement, speed, accelerations are defined as:

$$
\begin{aligned}
& x_{r}=x_{1}-x_{2} \\
& v_{r}=\dot{x}_{1}-\dot{x}_{2} \\
& \ddot{x}_{r}=\ddot{x}_{1}-\ddot{x}_{2}
\end{aligned}
$$

The friction factors are defined as:

$$
\begin{aligned}
& f_{1,1}=1 \pm \frac{\rho_{1,1} \mu_{1}}{r_{b 1}} \\
& f_{1,2}=1 \pm \frac{\rho_{1,2} \mu_{2}}{r_{b 1}} \\
& f_{2,1}=1 \pm \frac{\rho_{2,1} \mu_{1}}{r_{b 2}} \\
& f_{2,2}=1 \pm \frac{\rho_{2,2} \mu_{2}}{r_{b 2}}
\end{aligned}
$$

where,

$f_{1}, f_{2}=$ friction factors, $(-)$

If the above expressions are written in the Eq. (9) and Eq. (10) and these equations subtract each other, the new equation of motions is obtained as:

$$
\begin{aligned}
\ddot{x}_{r}+2\left[\frac{K_{1}\left(f_{1,1} m_{2}+f_{2,1} m_{1}\right)+K_{2}\left(f_{1,2} m_{2}+f_{2,2} m_{1}\right)}{m_{2} m_{1}}\right]^{1 / 2} \xi \dot{x}_{r} \\
+ \\
=\frac{K_{1}\left(f_{1,1} m_{2}+f_{2,1} m_{1}\right)+K_{2}\left(f_{2,2} m_{2}+f_{2,2} m_{1}\right)}{m_{2} m_{1}} x_{r} \\
=\frac{\left(m_{2} m_{1}\right) F_{s}+K_{1} e_{1}\left(s_{1,1} m_{2}+s_{2,1} m_{1}\right)+K_{2} e_{2}\left(s_{1,2} m_{2}+s_{2,2} m_{1}\right)}{m_{2} m_{1}}
\end{aligned}
$$

where,

$\xi=$ damping ratio (taken 0.17 according to the ref [8])

The equations of motions are solved by using the fourth-order Runge-Kutta method in MATLAB $^{\circledR}$. The ODE (Ordinary Differential Equations) functions of the MATLAB ${ }^{\circledR}$ are not used for the solution process, and the Runge-Kutta method is directly written by the authors. The flowchart of the study is given in Figure 4. 


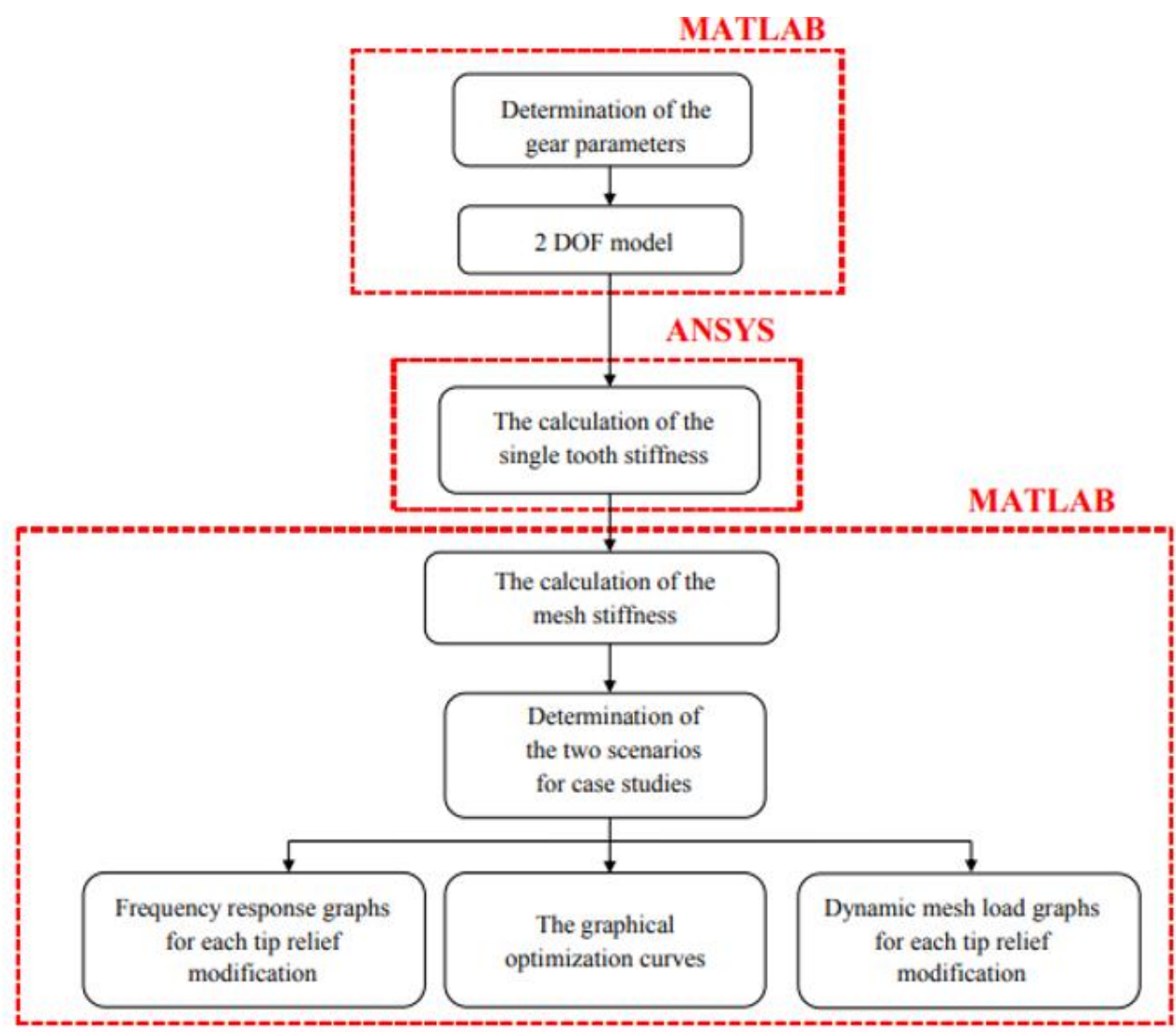

Figure 4:

Flowchart of the study

\section{RESULTS AND DISCUSSION}

In this study, the effects of linear short tip relief on gear dynamic loads are investigated numerically. In case 1, the ordinary gearbox conditions are simulated. Moreover, in case 2, a wind turbine application is simulated, according to Frazer et al. (2010). The gear properties of case studies are given in Table 1. All gear properties are taken constantly during the dynamic analysis except the amount of tip relief modification. The amount of tip relief modification is varied from $0-18 \mu \mathrm{m}$ for case 1 and from $0-35 \mu \mathrm{m}$ for case 2 .

Table 1. Gear data

\begin{tabular}{c|ccc} 
Parameters & Unit & Case 1 & Case 2 \\
\hline Module $\left(m_{n}\right)$ & $\mathrm{mm}$ & 3.18 & 7 \\
Pinion teeth number $\left(z_{l}\right)$ & - & 25 & 25 \\
Gear teeth number $\left(z_{2}\right)$ & - & 25 & 116 \\
Tooth face width $(b)$ & $\mathrm{mm}$ & 25.4 & 200 \\
Pressure angle $\left(\alpha_{0}\right)$ & $\mathrm{deg}$ & 20 & 20
\end{tabular}




\begin{tabular}{c|ccc} 
Mass of pinion $\left(m_{p}\right)$ & $\mathrm{kg}$ & 0.8113 & 108 \\
Mass of gear $\left(m_{g}\right)$ & $\mathrm{kg}$ & 0.8113 & 500 \\
Amount of tip modification & $\mu \mathrm{m}$ & $0-5-10-15-18$ & $0-10-20-28-35$ \\
Pinion profile shifting factor $\left(X_{p}\right)$ & - & 0 & 0 \\
Gear profile shifting factor $\left(X_{d}\right)$ & - & 0 & 0 \\
Addendum $\left(h_{a}\right)$ & $\mathrm{mm}$ & $1 * m_{n}$ & $1 * m_{n}$ \\
Dedendum $\left(h_{f}\right)$ & $\mathrm{mm}$ & $1.25 * m_{n}$ & $1.25 * m_{n}$ \\
Damping ratio $(\xi)$ & - & 0.17 & 0.17 \\
Material & - & Steel & Steel
\end{tabular}

The mesh forces between two teeth are taken into consideration to see the effect of the amount of tip relief modification. Furthermore, the frequency response of the gear system is evaluated. 1600 and $1000 \mathrm{rpm}$ are defined to see the mesh forces for both two cases. Mesh forces cannot be obtained clearly in the high operation speed of the pinion. According to the contact position of the line of contact, the change of mesh forces is presented in Figure 5 and Figure 6 for case 1 and case 2, respectively. The mesh forces are not stable due to the vibration of the gears. The mesh forces are lower in the double teeth pair region when it is compared to the single tooth pair region. When the contact reaches the single tooth pair region at the point "B," the dynamic forces make a pick, and maximum contact forces appear. The dynamic factor of the gearboxes is calculated by using this pick load. The dynamic factor can be calculated by using Eq. (21).

$$
D F_{\text {max }}=\frac{F_{\text {Dynamic } \max }}{F_{\text {static }}}
$$

\subsection{Case Studies}

The maximum dynamic loads are determined for gears with no tip relief modification in both cases. Until $15 \mu \mathrm{m}$ in case 1 and $28 \mu \mathrm{m}$ in case 2 , the dynamic factor is continuously decreased, as can be seen from Figure 5a, b, c, d and Figure 6a, b, c, d. After $15 \mu \mathrm{m}$ tip relief modification, the dynamic forces increase for case 1, and the same results are also observed for case 2 in 28 $\mu \mathrm{m}$. In gears with no tip relief modification, the dynamic factor is defined as 1.25 for both cases, as presented in Figure 5a and Figure 6a. For 1600 rpm, the minimum dynamic factor is obtained in $15 \mu \mathrm{m}$ tip relief modification; the dynamic factor is nearly 1 in this situation (Figure $5 \mathrm{~d}$ ). However, after $15 \mu \mathrm{m}$ tip relief modification in case 1, the dynamic loads begin to increase. 


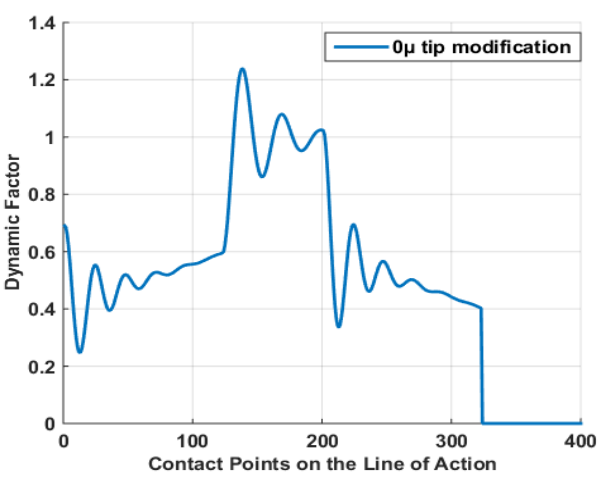

a.

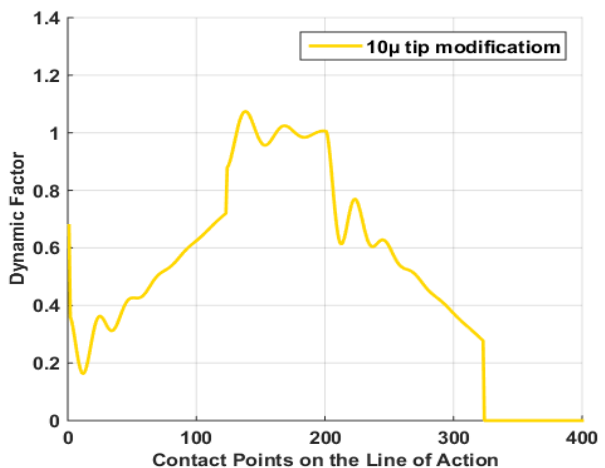

$c$

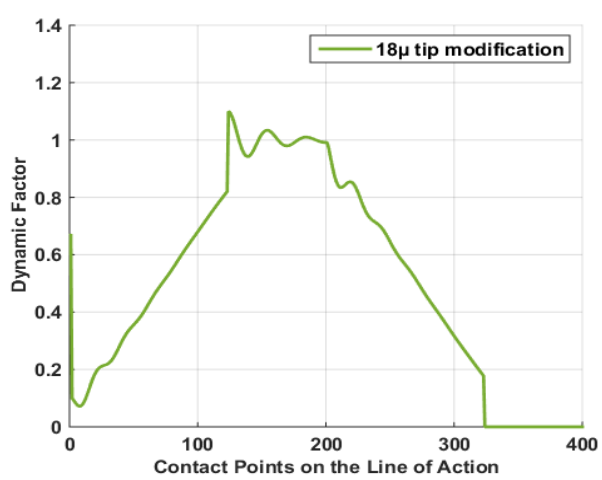

e.

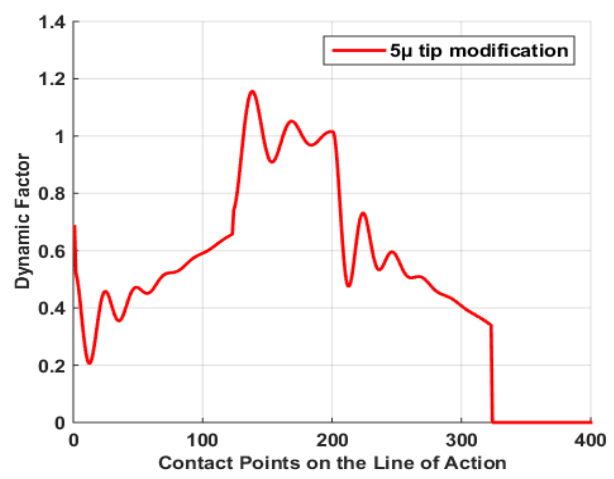

$b$.

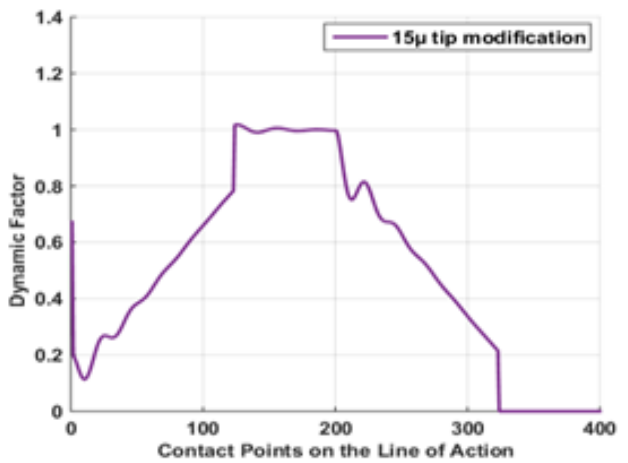

$d$.

Figure 5:

Dynamic mesh loads for 1600 rpm pinion speed with different tip relief modifications for case 1 a. $0 \mu \mathrm{m}$ b. $5 \mu \mathrm{m}$ c. $10 \mu \mathrm{m} \boldsymbol{d} .15 \mu \mathrm{m}$ and $\boldsymbol{e} .18 \mu \mathrm{m}$ tip modification

Similarly, for $1000 \mathrm{rpm}$, the minimum dynamic factor is obtained in $28 \mu \mathrm{m}$ tip relief modification in case 2 (Figure 6d). After $28 \mu \mathrm{m}$ tip relief modification, the dynamic loads also begin to increase. Thus, the amount of modification value should not be above a particular value. The frequency response of the gearboxes should be known to find this particular value. 


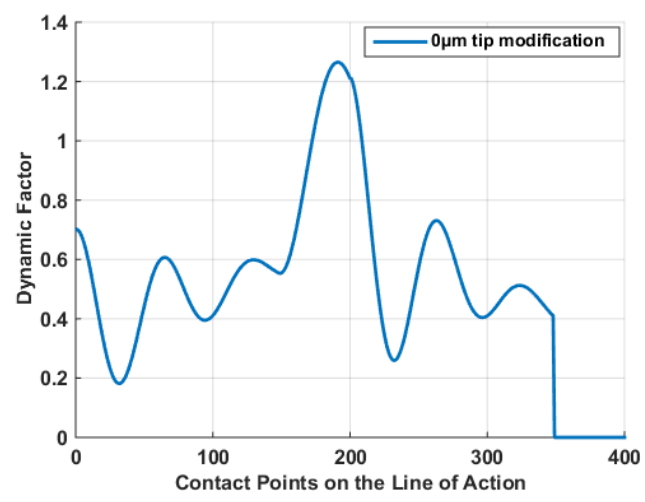

a.

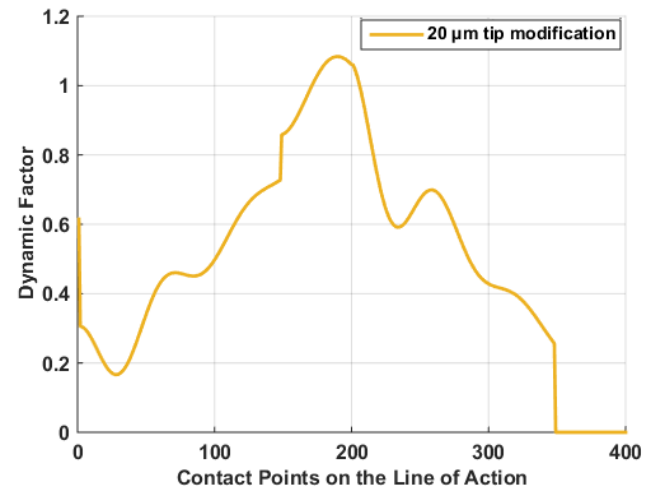

$c$.

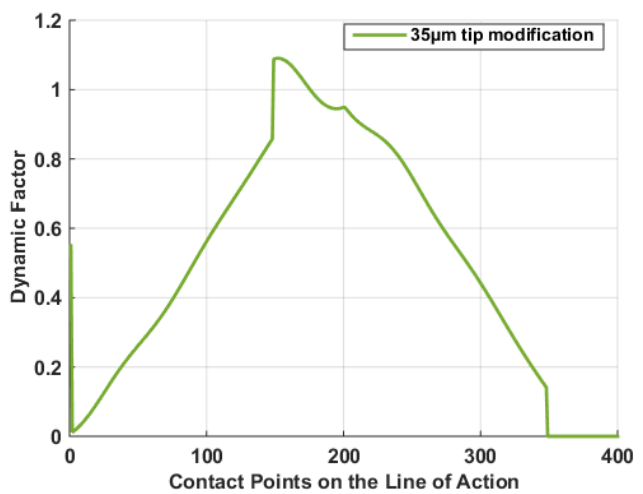

$e$.

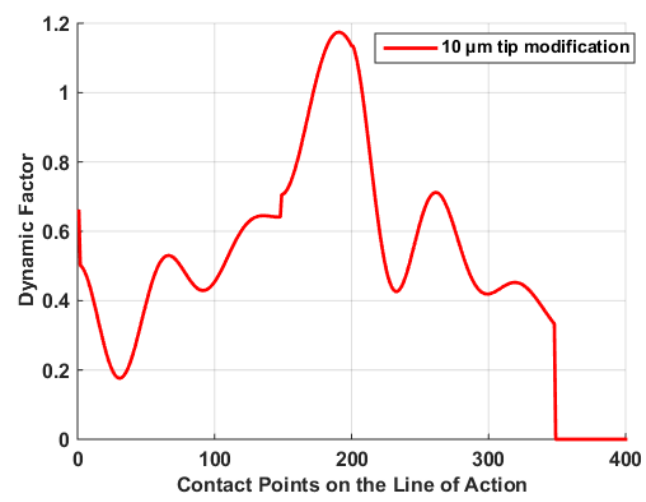

$b$.

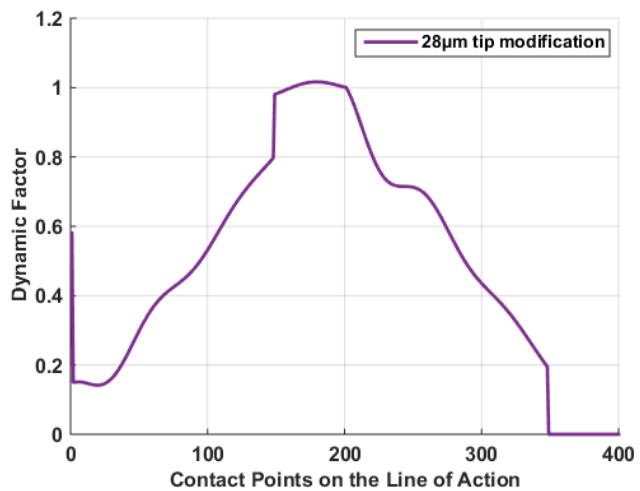

d.

Figure 6:

Dynamic mesh loads for 1000 rpm pinion speed with different tip relief modifications for case 2 a. $0 \mu \mathrm{m} \boldsymbol{b} .10 \mu \mathrm{m}$ c. $20 \mu \mathrm{m} \boldsymbol{d} .28 \mu \mathrm{m}$ and $\mathbf{e} .35 \mu \mathrm{m}$ tip modification

In this study, the range of 400 to $20000 \mathrm{rpm}$ (case 1) and 300 to $5000 \mathrm{rpm}$ (case 2) is defined as the frequency response interval. Starting from $400 \mathrm{rpm}$ and similarly from $300 \mathrm{rpm}$, for case 1 and case 2, the pinion revolution speed is increased by $60 \mathrm{rpm}$ each step, and the maximum dynamic factor is recorded. Thus, the frequency response curves of the gear system are created. Figure $7 \mathrm{a}$ and Figure $7 \mathrm{~b}$ show that the frequency response curves are given according to the amount of tip relief modification. There, two resonance regions are defined. The first resonance speed has observed at about $7500 \mathrm{rpm}$ for case 1 and $1400 \mathrm{rpm}$ for case 2 . In the first resonance 
region, the maximum dynamic factor is defined as 1.3 for case 1 , while it is defined as 1.32 for case 2 with no tip relief modification.

For case 1 , the minimum dynamic factor is defined as 1.03 for a $15 \mu \mathrm{m}$ tip relief modified gear pair. The second resonance region is detected at about $15000 \mathrm{rpm}$ pinion speed. The second resonance region can be interpreted as being more dangerous than the first resonance region. The maximum dynamic factor is defined as 1.48 for $0 \mu \mathrm{m}$ tip relief modification. The minimum dynamic factor is defined as 1.16 for $15 \mu \mathrm{m}$ tip relief modification. After $15 \mu \mathrm{m}$, the dynamic factor increased.

Moreover, the maximum dynamic factor is defined as 1.32 for $0 \mu \mathrm{m}$ tip relief modification for case 2. The minimum dynamic factor is defined as 1.017 for a $28 \mu \mathrm{m}$ tip relief modified gear pair. After $28 \mu \mathrm{m}$, the dynamic factor increased.

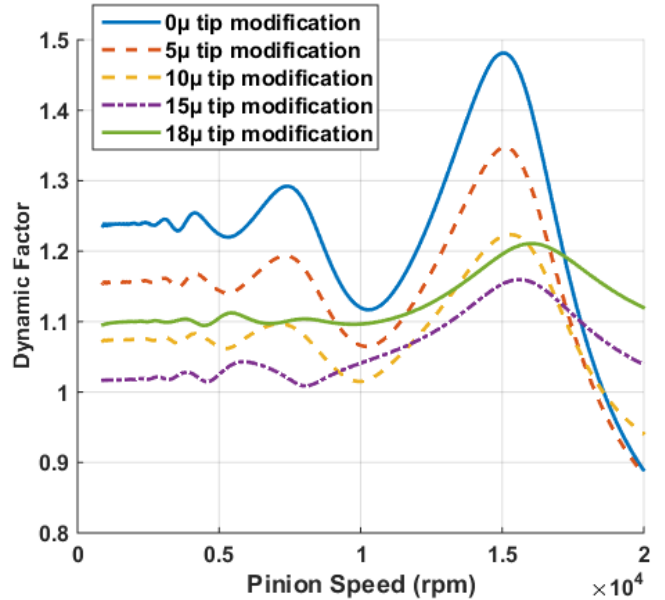

$a$.

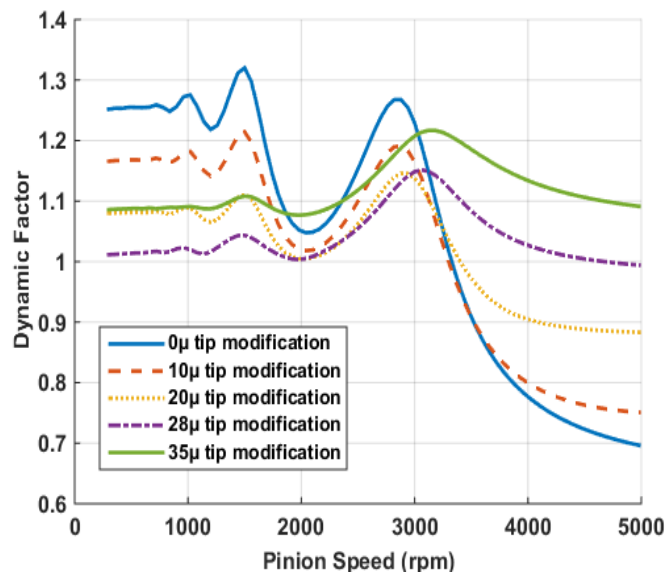

$b$.

Figure 7:

The frequency response of the gearboxes with different tip relief modifications a. Case 1 b. Case 2

Due to the behavior of the dynamic factor, an optimization study is needed to find the optimum amount of tip relief modification. In this study, the graphical optimization technique is used to find the optimum amount of tip relief modification. The frequency response curves are used to find the maximum dynamic factor. Maximum dynamic factor values are calculated.

In Figure 8, dynamic factor variation is given according to the amount of tip relief modification. The minimum dynamic factor is observed with tip relief modification values of 15 $\mu \mathrm{m}$ for case 1 and $28 \mu \mathrm{m}$ for case 2 . After these values, the dynamic loads begin to increase for both cases. Thus, the designers should know the optimum value of the amount of tip relief modification for designing minimum dynamic loads, lower noise, and minimum vibration. 


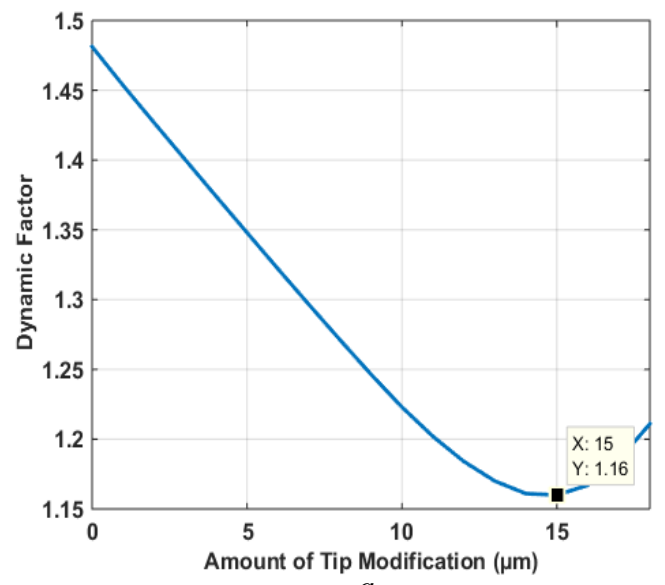

a.

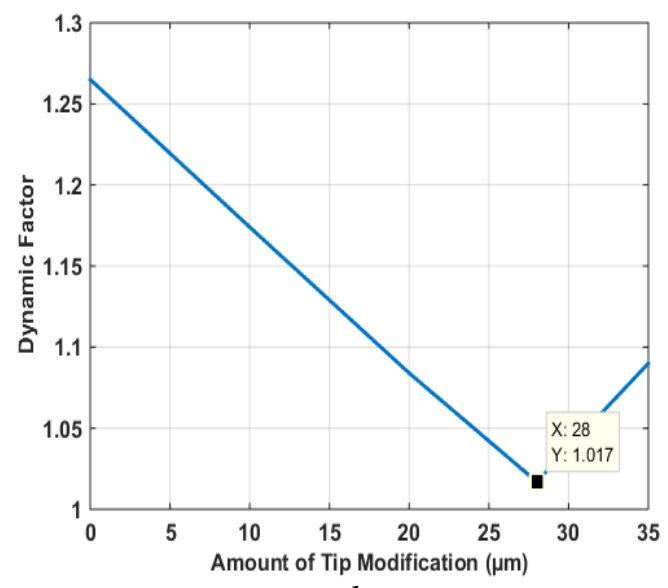

$b$.

Figure 8:

Graphical optimization curve for the different amount of tip modification

a. Case 1 b. Case 2

\section{CONCLUSIONS}

Tip relief modification is a powerful way to decrease dynamic loads, noise, and vibration of gear systems. In this study, the effects of linear short tip relief modification on dynamic loads are investigated numerically. The single tooth stiffness is calculated by using the finite element method, and gear equivalent mesh stiffness is calculated. A two-degree-of-freedom dynamic model is developed to find the dynamic loads. The equations of motions are solved by using the fourth-order Runge-Kutta method. Thus, dynamic loads are obtained for one cycle gear mesh position. Different amount of tip relief modifications is applied to the gears as the case studies. The results are gained for 1600 and $1000 \mathrm{rpm}$ and between $400-20000 \mathrm{rpm}$ and $300-5000 \mathrm{rpm}$, respectively, for case studies as the frequency response. Both results show that, until a certain amount of tip relief modification, the dynamic loads continuously decrease. However, after the $15 \mu \mathrm{m}$ tip relief modification for case 1 and $28 \mu \mathrm{m}$ tip relief modification for case 2 , the dynamic loads begin to increase. Thus, an optimization study is needed to find the optimum amount of tip relief modification. To achieve this aim, the graphical optimization method is used. The maximum dynamic factors are recorded for each amount of tip relief modification, and the minimum level of dynamic factor can be obtained easily. The dynamic factor behaves like a "V form" according to the tip relief modification. It can be concluded that the written computer program could be a considerable alternative for wind turbine gearbox designers in the future.

\section{CONFLICT OF INTEREST}

Authors approve that to the best of their knowledge, there is not any conflict of interest or common interest with an institution/organization or a person that may affect the review process of the paper.

\section{AUTHOR CONTRIBUTION}

Oğuz DOĞAN contributed to the determination and management of the conceptual and design processes of the study, data collection, data analysis and interpretation, preparation of the manuscript, final approval, and full responsibility. Onur Can KALAY contributed to the determination of the conceptual and design processes of the study, data collection, data analysis and interpretation, preparation of the manuscript, final approval, and full responsibility. Fatih 
KARPAT contributed to the determination and management of the conceptual process of the study, data analysis and interpretation, critical analysis of the intellectual content, final approval, and full responsibility.

\section{REFERENCES}

1. Alemayehu, F.M. and Ekwaro-Osire, S. (2014) Loading and design parameter uncertainty in the dynamics and performance of high-speed-parallel-helical stage of a wind turbine gearbox, Journal of Mechanical Design, 136(9). https://doi.org/10.1115/1.4027496.

2. Baud, S. and Velex, P. (2002) Static and dynamic tooth load in spur and helical geared systems - experiments and model validation, Journal of Mechanical Design, 124(2), 334 346. https://doi.org/10.1115/1.1462044.

3. Ding, F., Tian, Z., Zhao, F. and Xu, H. (2018) An integrated approach for wind turbine gearbox fatigue life prediction considering instantaneously varying load conditions, Renewable Energy, 129, 260 - 270. https://doi.org/10.1016/j.renene.2018.05.074.

4. Frazer, R.C., Shaw, B.A., Palmer, D. and Fish, M. (2010) Application examples from optimizing gear geometry for minimum transmission error, mesh friction losses and scuffing risk through computer-aided engineering, Gear Technology, August.

5. Guerine, A., El-Hami, A., Walha, L., Fakhfakh, T. and Haddar, M. (2017) Dynamic response of wind turbine gear system with uncertain-but-bounded parameters using interval analysis method, Renewable Energy, 113, 679 - 687. https://doi.org/10.1016/j.renene.2017.06.028.

6. Hu, Z., Tang, J., Zhong, J., Chen, S. and Yan, H. (2016) Effects of tooth profile modification on dynamic responses of a high speed gear-rotor-bearing system, Mechanical Systems and Signal Processing, 76(77), 294 - 318. https://doi.org/10.1016/j.ymssp.2016.01.020.

7. Kahraman, A. and Blankenship, G.W. (1999) Effect of involute tip relief on dynamic response of spur gear pairs, Journal of Mechanical Design, 121(2), 313 - 315. https://doi.org/10.1115/1.2829460.

8. Karpat, F., Ekwaro-Osire, S., Cavdar, K. and Babalik, F.C. (2008) Dynamic analysis of involute spur gears with asymmetric teeth, International Journal of Mechanical Sciences, 50(12), 1598 - 1610. https://doi.org/10.1016/j.ijmecsci.2008.10.004.

9. Karpat, F. and Ekwaro-Osire, S. (2008) Influence of tip relief modification on the wear of spur gears with asymmetric teeth, Tribology Transactions, 51(5), 581 - 588. https://doi.org/10.1080/10402000802011703.

10. Karpat, F. and Ekwaro-Osire, S. (2008) Dynamic analysis of high-contact-ratio spur gears with asymmetric teeth, Proceedings of the ASME International Mechanical Engineering Congress and Exposition, Boston, Massachusetts, $285-291$. https://doi.org/10.1115/IMECE2008-67838.

11. Karpat, F., Dogan, O., Yuce, C. and Ekwaro-Osire, S. (2017) An improved numerical method for the mesh stiffness calculation of spur gears with asymmetric teeth on dynamic load analysis, Advances in Mechanical Engineering, 9(8), 1 - 12. https://doi.org/10.1177/1687814017721856.

12. Karpat, F., Yuce, C., and Dogan, O. (2020) Experimental measurement and numerical validation of single tooth stiffness for involute spur gears, Measurement, 150. https://doi.org/10.1016/j.measurement.2019.107043.

13. Lin, H.H., Huston, R.L. and Coy, J.J. (1990) Dynamic loads in parallel shaft transmissions part 1, Gear Technology, March/April, 25 - 34. 
14. Lin, H.H., Huston, R.L. and Coy, J.J. (1990) Dynamic loads in parallel shaft transmissions part 2, Gear Technology, May/June, 8-27.

15. Lin, H.H., Oswald, F.B. and Townsend, D.P. (1994) Dynamic loading of spur gears with linear or parabolic tooth profile modifications, Mechanism and Machine Theory, 29(8), 1115 - 1129. https://doi.org/10.1016/0094-114X(94)90003-5.

16. Liou, C.H., Lin, H.H., Oswald, F.B. and Townsend, D.P. (1996) Effect of contact ratio on spur gear dynamic load with no tooth profile modifications. Journal of Mechanical Design, 118(3), 439 - 443. https://doi.org/10.1115/1.2826905.

17. Liu, H., Zhang, C., Xiang, C.L. and Wang, C. (2016) Tooth profile modification based on lateral-torsional-rocking coupled nonlinear dynamic model of gear system, Mechanism and Machine Theory, 105, 606 - 619. https://doi.org/10.1016/j.mechmachtheory.2016.07.013.

18. Marković, K. and Franulović, M. (2011) Contact stresses in gear teeth due to tip relief profile modification, Engineering Review, 31(1), 19 - 26.

19. Marković, K. and Vrcan, Z. (2016) Influence of tip relief modification an involute spur gear stress, Transactions of Famena, 40(2), 59 - 70. https://doi.org/10.21278/TOF.40205.

20. Marques, M.T., Martins, R.C. and Seabra, J.H.O. (2016) Gear dynamics and power loss. Tribology International, 97, 400 - 411. https://doi.org/10.1016/j.triboint.2016.02.002.

21. Ozguven, H.N. (1991) A non-linear mathematical model for dynamic analysis of spur gears including shafts and bearing dynamics, Journal of Sound and Vibration, 145(2), $239-260$. https://doi.org/10.1016/0022-460X(91)90590-G.

22. Palmer, D. and Fish, M. (2012) Evaluation of methods for calculating effects of tip relief on transmission error, noise and stress in loaded spur gears, Gear Technology, January/February, $56-67$.

23. Shanmugasundaram, S., Kumaresan, M. and Muthusamy, N. (2014) Effects of pressure angle and tip relief on the life of speed increasing gearbox: A case study, SpringerPlus, 3(1), 1 10.

24. Tharmakulasingam, R., Alfano, G. and Atherton, M. (2008) Reduction of gear pair transmission error with tooth profile modification. Proceedings of the ISMA 2008 International Conference on Noise and Vibration Engineering, Leuven, Belgium.

25. Tharmakulasingam, R. (2009) Transmission error in spur gears: Static and dynamic finiteelement modeling and design optimization, Ph.D. Thesis, Brunel University.

26. Wei, S., Zhao, J., Han, Q. and Chu, F. (2015) Dynamic response analysis on torsional vibrations of wind turbine geared transmission system with uncertainty, Renewable Energy, 78, 60 - 67. https://doi.org/10.1016/j.renene.2014.12.062.

27. Yildirim, N. and Munro, R.G. (1999) A systematic approach to profile relief design of low and high contact ratio spur gears, Proceedings of the Institution of Mechanical Engineers Part C, 213(6), 551 - 562. https://doi.org/10.1243/0954406991522482.

28. Yoon, K.Y. and Rao, S.S. (1996) Dynamic load analysis of spur gears using a new tooth profile, Journal of Mechanical Design, 118(1), 1 - 6. https://doi.org/10.1115/1.2826851. 
